\title{
Design and Synthesis of Single Nanoparticle Optical Biosensors for Imaging and Characterization of Single Receptor Molecules on Single Living Cells
}

\author{
Tao Huang $§, 1$, Prakash D. Nallathamby $§, 1$, Daniel Gillet ${ }^{2}$, and Xiao-Hong Nancy Xu ${ }^{*}{ }^{2} 1$ \\ 1Department of Chemistry and Biochemistry, Old Dominion University, Norfolk, VA 23529 \\ 2 Commissariat à l'Energie Atomique (CEA), Institut de Biologie et Technologies de Saclay (iBiTecS), Service \\ d'Ingénierie Moléculaire des Protéines (SIMOPRO), F-91191 Gif sur Yvette, France.
}

\begin{abstract}
At the cellular level, a small number of protein molecules (receptors) can induce significant cellular responses, emphasizing the importance of molecular detection of trace amounts of protein on single living cells. In this study, we designed and synthesized silver $(\mathrm{Ag})$ nanoparticle biosensors (AgMMUA- $\operatorname{IgG}$ ) by functionalizing $(11.6 \pm 3.5) \mathrm{nm} \mathrm{Ag} \mathrm{nanoparticles} \mathrm{with} \mathrm{a} \mathrm{mixed} \mathrm{monolayer} \mathrm{of}$ 11-mercaptoundecanoic acid (MUA) and 6-mercapto-1-hexanol (MCH) (1:3 mole ratio), and covalently conjugating $\operatorname{IgG}$ with MUA on the nanoparticle surface. We found that the nanoparticle biosensors preserve their biological activity and photostability and can be utilized to quantitatively detect individual receptor molecules (T-ZZ), map the distribution of receptors $(0.21-0.37$ molecule/ $\mu \mathrm{m}^{2}$ ), and measure their binding affinity and kinetics at concentrations below their dissociation constant, on single living cells in real time over hrs. The dynamic range of detection is $0-50$ molecules per cell. We also found that the binding rate (2-27 molecules/min) is highly dependent upon the coverage of receptors on living cells and their ligand concentration. The binding association and dissociation rate constants and affinity constant are $k_{1}=(9.0 \pm 2.6) \times 10^{3} \mathrm{M}^{-1} \mathrm{~s}^{-1}, k_{-1}=(3.0 \pm 0.4)$ $\times 10^{-4} \mathrm{~s}^{-1}$, and $\mathrm{K}_{\mathrm{B}}=(4.3 \pm 1.1) \times 10^{7} \mathrm{M}^{-1}$, respectively.
\end{abstract}

\section{Keywords}

Single nanoparticle biosensors; single molecule detection; living cell imaging; single living cells; fusion protein; membrane protein; single ligand and receptor; Protein A; IgG

\section{Introduction}

Biological systems can respond to extremely low levels of various protein molecules (antigen, ligand, receptor). ${ }^{1-3}$ For instance, individual T-lymphocytes binding with $\sim 10$ molecules of interleukin-2 can lead to the production of interleukin-1 and a cascade of other vital immune responses. ${ }^{4}$ At such low concentrations (far below the dissociation constant), conventional analytical tools are unable to effectively detect these vital molecules. Furthermore, classical kinetic theories based upon the law of mass action are unlikely to be applicable to the study of binding mechanisms of individual protein molecules. Thus, a stochastic approach is required to describe the binding kinetics of individual protein-protein interactions. Single molecule

\footnotetext{
*To whom correspondence should be addressed: Email: xhxu@odu.edu; www.odu.edu/sci/xu/xu.htm; Tel/fax: (757) 683-5698.

$\S$ These authors contributed equally to this work.
} 
detection (SMD) offers the required detection sensitivity and stochastic measurement to solve such challenging problems.

Currently, the primary methods for the detection of protein molecules include UV-vis spectroscopy, immunohistochemistry and radioactive detection assays $\left({ }^{3} \mathrm{H}\right)$. Some of these methods require proteins to be isolated from bulk cells. Typically, these methods also involve several washing steps and hence are time-consuming and cannot measure protein-protein interactions on living cells in real-time. Recently, confocal fluorescence microscopy has been used to map proteins on living cells. However, fluorescence probes suffer photobleaching and single fluorophor molecules exhibit blinking. Thus, high numbers of fluorescence dye molecules typically are needed to label antibodies in order to detect and characterize individual receptors on living cells for sufficient lengths of time. ${ }^{5}$ Unfortunately, only limited numbers of the dye molecules can be conjugated with individual antibody molecules. Thus, it remains challenging to detect individual protein molecules on living cells and to follow their binding mechanisms for an extended period of time. Furthermore, many of these detection schemes are still based upon immunoenzymatic assay and cell-staining techniques, which includes several washing steps.

Recently, atomic force microscopy (AFM) has also been used to detect protein-protein interactions on solid surfaces (e.g., gold, mica) using force measurements. ${ }^{6}$ Unlike smooth solid surfaces, the living cell surface is not rigid, which presents a challenge for force measurement. Furthermore, the ligand has to be immobilized on the AFM tip and using the tip to locate the few receptors scattered on the living cell surface offers limited temporal resolution for measuring the binding rates.

Although noble metal nanoparticles ( $\mathrm{Au}, \mathrm{Ag}$ ) randomly attached with antibodies using electrostatic interaction have been widely used as nanoparticle probes to detect antigens on cell surface using transmission electron microscopy (TEM) ${ }^{7}, 8$, cell death occurs under the vacuum of TEM. Thus, such methods cannot measure kinetics (binding rates) of protein-protein interactions on living cells. Recently, Ag and Au nanoparticles have been used for sensing proteins in solution ${ }^{9-12}$ and to study transport dynamics in living cells, ${ }^{13-17}$ showing the great potential of SMD. ${ }^{15,17,18}$ A variety of approaches have been reported for SMD in solution $5,17,19-23$ and in living cells $15,17,24-26$. However, the study of specific interactions of individual protein-protein interactions on living cells still remains challenging. 17

In this study, we have developed non-photobleaching, non-blinking single Ag nanoparticle biosensors to quantitatively measure the binding kinetics and affinity of single protein molecules on single living cells for an extended period of time (hours) (Fig. 1), using our single nanoparticle optical microscopy and spectroscopy (SNOMS). ${ }^{13,15,16,27}$ The Ag nanoparticles can be directly imaged based upon the high quantum yield (QY) of their Raleigh scattering, using a detection scheme with no need of fluorescence excitation, which effectively avoids auto-fluorescence of living cells and significantly improves the signal-to-noise ratio of SMD on single living cells.

We fused a functional protein (ZZ, small portion of PrA, IgG-Fc binding protein, acting as a receptor for $\operatorname{IgG}$ ) with a transmembrane domain, the translocation $(\mathrm{T})$ domain of the diphtheria toxin, to prepare $\mathrm{T}-\mathrm{ZZ}^{28-30}$, and anchored the T-ZZ onto living cell membranes to create the desired coverage of individual ZZ molecules on the living cell surface, mimicking individual antigen and receptor molecules on living cells (Fig. 1).

The T domain includes ten $\alpha$-helices (TH1-9 and TH5'). ${ }^{31}$ Helices TH8-9 are highly hydrophobic, and are sandwiched and hidden from water by two layers of amphiphilic helices (TH1-4 and TH5-7). Thus, the T domain is fully soluble at neutral $\mathrm{pH}$. When exposed to an 
acidic $\mathrm{pH} \leq 5.0$, the $\mathrm{T}$ domain changes its conformation as the three groups of helices come apart, leading to amphiphilic helices (TH1-7) floating at the hydrophobic/hydrophilic interface of the cellular membrane surface and the hydrophobic hairpin TH8-9 inserting into the hydrophobic lipid bilayer ${ }^{28,32}$ (Fig. 1C). Thus, T domain anchors onto the surface of cell membrane at $\mathrm{pH} 4.8$ and remains on the membrane surface as the $\mathrm{pH}$ is switched back to 7.4. Pervious studies have demonstrated that T-ZZ retains its biological activity and binding affinity after being incubated at $\mathrm{pH} 4.8$ for $80 \mathrm{~min}$, and T-ZZ remains anchored on the living cell surface and does not internalize into the living cells. ${ }^{28-30}$

With this approach, we generated a clean and affordable model system to validate and optimize single nanoparticle biosensors for detecting the binding affinity and kinetics of individual protein molecules on single living cells in real time. The approach using the $\mathrm{T}$ domain fusion protein as a pH-dependent membrane anchor is much simpler to quantitatively control the number of protein molecules on living cells than using molecular biology techniques to control the expression level of proteins on living cells. This approach also demonstrates the possibility of fabricating and altering a living cellular surface with functional receptors, offering new opportunities to engineer the cell surface without gene transfection, which have shown potential therapeutic applications (e.g., design of anticancer vaccines) $)^{33}$.

\section{Experimental Section}

\section{Reagents and Supplies}

Sodium citrate dihydrate ( $\geq 99 \%), \mathrm{AgClO}_{4}(\geq 99.9 \%), \mathrm{NaBH}_{4}(\geq 98 \%), 11$ mercaptoundecanoic acid (MUA $\geq 95 \%$ ), 6-mercapto-1-hexanol (MCH) $(\geq 97 \%)$, trypan blue $(0.4 \%)$, immunoglobulin $\mathrm{G}$ from rabbit serum $(\operatorname{IgG} \geq 95 \%)$, Protein $\mathrm{A}(\operatorname{PrA})$ from Staphylococcus aureus ( $\geq 95 \%$ ), collagen from calf skin, bovine serum albumin (BSA), $30 \mathrm{kDa}$ poly(ethylene glycol) (PEG), and ethanol $(\geq 99.8 \%)$ were purchased from Sigma-Aldrich. 1Ethyl-3-[3-dimethylaminopropyl]-carbodiimide hydrochloride (EDC $\geq 99 \%$ ) and $\mathrm{N}$ hydroxysulfosuccinimide (Sulfo-NHS $\geq 98.5 \%$ ) are purchased from Pierce. Dulbecco's modified eagle's medium (DMEM) 1X medium, 100X Penicillin-Streptomycin-Glutamine Solution (P-S-G), Fetal Bovine Serum (FBS), Hanks' Balanced Salt Solution (HBSS, without $\mathrm{Ca}^{2+}, \mathrm{Mg}^{2+}$ and phenol red; $\mathrm{pH}=7.4$ ), and mouse fibroblast cells (L292) were purchased from ATCC. The T-ZZ was constructed by fusing the C-terminus of transmembrane domain (T) of diphtheria toxin (a $58 \mathrm{kD}$ soluble protein) with $\mathrm{ZZ}$ using protein-engineering techniques. ${ }^{28-}$ 30 The $\mathrm{T}$ domain $(22 \mathrm{kD})$ isolated from the rest of diphtheria toxin ${ }^{34}$ is devoid of toxicity. All solutions, including $10 \mathrm{mM}$ phosphate buffer $(\mathrm{PB})(\mathrm{pH}=7.4), 10 \mathrm{mM}$ phosphate buffer saline (PBS) $(\mathrm{pH}=7.4)$ and $10 \mathrm{mM}$ citrate phosphate buffer saline $(\mathrm{pH}=4.8)$, were prepared using nanopure water (Barnstead).

\section{Synthesis and Characterization of Single Nanoparticle Biosensors}

Ag Nanoparticles-The sodium citrate $(3 \mathrm{mM})$ and $\mathrm{NaBH}_{4}(10 \mathrm{mM})$ in nanopure water $(495 \mathrm{~mL})$ was prepared freshly and stirred constantly at $0^{\circ} \mathrm{C}$. As $\mathrm{AgClO}_{4}(5 \mathrm{~mL}, 10 \mathrm{mM})$ was added into the solution, the color of the solution changes from colorless to yellow. After stirring for $4 \mathrm{hr}$ at room temperature, the solution was filtered using $0.2 \mu \mathrm{m}$ membrane filters. The diameter of Ag nanoparticles is $11.6 \pm 3.5 \mathrm{~nm}$ as characterized by HRTEM (FEI Tecnai G2 F30 FEG) and dynamic light scattering (DLC) (Nicomp 380ZLS particle sizing system).

AgMMUA Nanoparticles-The mixture (5 mL) of MUA $(10 \mathrm{mM})$ and $\mathrm{MCH}(90 \mathrm{mM})$ in ethanol was added into the freshly prepared $\mathrm{Ag}$ nanoparticle solution $(500 \mathrm{~mL})$ and stirred for $48 \mathrm{hr}$. The AgMMUA nanoparticles were harvested and washed twice with nanopure water to remove excess thiol by centrifugation $\left(12,000 \mathrm{rpm}, 4^{\circ} \mathrm{C}, \sim 150 \mathrm{~min}\right)$. The AgMMUA nanoparticles were characterized using UV-Vis spectroscopy (Hitachi U3310), NMR (400 
MHz, Bruker), DLC, and SNOMS. NMR samples were prepared by rinsing AgMMUA nanoaprticles with nanopure water three times using centrifugation, dialyzing using a $30 \mathrm{kDa}$ cut-off member, drying using lyophilization (VirTis), and dissolving $50 \mathrm{mg}$ of AgMMUA nanoparticles in $1.0 \mathrm{~mL} \mathrm{D}_{2} \mathrm{O}$.

AgMMUA-IgG Nanoparticles-The EDC ( $26.4 \mathrm{nmol})$ and sulfo-NHS $(35.2 \mu$ mole) were added to AgMMUA aqueous solution ( $3 \mathrm{~mL}, 80 \mathrm{nM}$ ), to generate AgMMUA-s-NHS. After stirring at room temperature for $40 \mathrm{~min}$, AgMMUA-s-NHS was de-salted using a Centriprep YM-30 (Millipore) by centrifugation at $1500 \mathrm{rcf}$ (relative-centrifuge-force) to remove excess EDC and sulfo-NHS, and then re-dissolved in PBS buffer. PEG $(0.05 \% \mathrm{w} / \mathrm{v})$ was added to block any possible non-specific binding sites on the AgMMUA nanoparticles and to prevent non-specific adsorption of IgG onto the surface during the following linking reaction. Then, IgG was added to AgMMUA-s-NHS in PBS buffer to a mole ratio of IgG to AgMMUA at 0.97 . The solution was mixed using a rotary shaker at room temperature for $2 \mathrm{hr}$, and then at $4{ }^{\circ} \mathrm{C}$ for $12 \mathrm{hr}$. The final product (AgMMUA-IgG nanoparticles) was washed with PBS buffer to remove excess IgG using centrifugation $\left(10,500 \mathrm{rpm}, 4^{\circ} \mathrm{C}, \sim 90 \mathrm{~min}\right)$. The pellet was resuspended and stored in PBS buffer containing $0.05 \%$ w/v PEG at $4{ }^{\circ} \mathrm{C}$ for future use.

PrA in PBS buffer solution was added into the AgMMUA-IgG nanoparticle solution in a quartz cuvette and carefully mixed by pipette. The UV-vis spectra of the mixture was measured immediately and followed for $24 \mathrm{hr}$ to monitor the binding kinetics of AgMMUA-IgG with PrA. The spectra were taken every $5 \mathrm{~min}$ at room temperature for the first $2 \mathrm{hr}$ and then every $2.5 \mathrm{hr}$ for $24 \mathrm{hr}$. The solution was stored at $4{ }^{\circ} \mathrm{C}$ to prevent denaturation of the proteins between spectroscopy measurements.

\section{Cell Culture and Viability Assay}

The fibroblast cells (L929) were first grown in a culture flask using the medium (DMEM 1X with $1 \%$ P-S-G and 10\% FBS). When the cells reached $80 \%$ confluence, they were transferred from the flask and cultured directly on sterile coverslips which were pre-coated with $1 \mathrm{mg} / \mathrm{mL}$ collagen in $0.1 \mathrm{M}$ acetic acid solution, rinsed and dried. The cells $\left(0.1 \mathrm{~mL}, 1 \times 10^{6}\right.$ cells $\left./ \mathrm{mL}\right)$ were carefully added onto each coverslip to ensure uniform coverage and allowed to adhere onto the coverslips. The cell medium was then added to cover the coverslips in Petri dishes, which were placed in a $\mathrm{CO}_{2}$ incubator $\left(5 \% \mathrm{CO}_{2}, 100 \%\right.$ humidity, $\left.37^{\circ} \mathrm{C}\right)$ overnight. We also investigated cell viability through the entire experiment using a Trypan blue cell viability assay. The cells incubated with Trypan blue $(0.4 \%)$ were imaged within 5 min incubation time at the single-cell resolution using bright field microscopy, and stained (dead) and unstained (viable) cells were counted. More than 300 cells in total were investigated for each data point.

\section{Imaging and Characterization of Single Receptor Molecules on Single Living Cells}

The living cells $\left(10^{5}\right)$ cultured on each coverslip were thoroughly rinsed with HBSS buffer $(\mathrm{pH}=7.4)$ and PBS-citrate buffer ( $\mathrm{pH} 4.8)$ to remove the medium, and incubated with $40 \mu \mathrm{L}$ of 0.10 or $1.0 \mu \mathrm{M} \mathrm{T}-\mathrm{ZZ}$ in PBS-citrate buffer at $4^{\circ} \mathrm{C}$ for $45 \mathrm{~min}$ to anchor T-ZZ on the cell surface. The cells were first rinsed with PBS-citrate buffer, then with HBSS buffer to thoroughly remove unbound T-ZZ, and finally incubated with $1 \mu \mathrm{M}$ BSA protein in HBSS buffer for $15 \mathrm{~min}$, aiming to block any possible non-specific interaction of the cell membrane with protein (AgMMUA-IgG), and rinsed thoroughly with HBSS buffer to remove unbound BSA.

The cells on the coverslips were placed onto the slides and incubated with AgMMUA-IgG nanoaprticles $(1.39,2.78,5.56$ and $11.12 \mathrm{nM})$ in PBS buffer $(\mathrm{pH}=7.4)$ in a well-sealed chamber created on the slide, and imaged using our SNOMS at given reaction times of 0-180 min (0, $20,40,60,80,100,120,150$, and $180 \mathrm{~min}$ ). Water droplets were scattered around the slide to 
maintain humidity, preventing possible evaporation of buffer solution inside the chamber. The nanoparticle concentrations were calculated as described in our previous study and presented in SI. 16,35

SNOMS has been well described in our previous studies for real-time imaging and spectroscopic characterization of single nanoparticles on single living cells and for single molecule detection. 13, 15, 16, 23, 25, 27, 36 The detectors (5MHz Micromax CCD camera and color digital camera) were used for imaging of single nanoparticles (Ag, AgMMUA, AgMMUA-IgG) and single living cells, and EMCCD or LN back-illuminated CCD camera coupled with a SpectraPro-150 (Roper Scientific) was used for measuring localized surface plasmon resonance spectra (LSPRS) of single nanoparticles.

Three blank control experiments were carried out simultaneously for each experiment: cells anchored with two surface coverages of T-ZZ prepared exactly the same as described above were incubated with $11.12 \mathrm{nM}$ AgMMUA nanoparticles (not yet conjugated with $\mathrm{IgG}$ ) and imaged for 0-180 min; cells without attaching of T-ZZ were incubated with $11.12 \mathrm{nM}$ AgMMUA-IgG nanoparticles and imaged exactly the same way.

Data Analysis and Statistics-At each given reaction time, the cells at 15-20 representative locations on the coverslips were imaged and at least 40 cells were studied for each measurement. Each experiment was repeated at least three times. Thus, 120 cells per data point were imaged to gain sufficient statistics to represent the bulk cells at single-cell resolution.

\section{Results and Discussion}

\section{Synthesis and Characterization of Single Nanoparticle Biosensors}

We synthesized nearly monodispersed (11.6 $\pm 3.5 \mathrm{~nm}$ in diameter) Ag nanoparticles as characterized by HRTEM (shown in Fig. 1Sof supporting information (SI)) by carefully selecting experimental conditions for reduction of $\mathrm{AgClO}_{4}$ with sodium citrate and $\mathrm{NaBH}_{4}$. Then, we functionalized these $\mathrm{Ag}$ nanoparticles with a mixed monolayer of MUA and $\mathrm{MCH}$ using the interaction of the thiol group (-SH) with the Ag nanoparticle surface to prepare AgMMUA (Fig. 1).

Note that the Ag nanoparticles were stabilized in solution by electrostatic repulsion of the surface adsorbed charged citrate layer. ${ }^{37-39}$ If only MUA was used to replace adsorbed citrate layer, the replacement reaction would follow a unimolecular nucleophilic substitution $\left(\mathrm{S}_{\mathrm{N}} 1\right)$ mechanism, because the citrate is a very good leaving group, and the charge-repulsion and steric hindrance of MUA makes an $\mathrm{S}_{\mathrm{N}} 2$ mechanism nearly impossible to occur. ${ }^{37-39}$ Thus, the presence of the MUA would accelerate the dissolving of the charged citrate layer, leading to the aggregation of nanoparticles, which is the major problem in synthesis of $\omega$ mercaptoalkanoic acids modified Ag nanoparticles.

To solve this problem, we used a mixture of MUA and $\mathrm{MCH}$ with a mole ratio of 1: 9. The presence of an excess of non-charged short chain $\mathrm{MCH}$ allows the substitution reaction more favorable to a $\mathrm{S}_{\mathrm{N}} 2$ mechanism, which prevents the aggregation of the Ag nanoparticles. The hydroxyl group on the end of $\mathrm{MCH}$ makes the functionalized Ag nanoparticles more hydrophilic. Since MCH is much shorter than MUA, it will not block the carboxyl group of the MUA for further linking with IgG. The short chain of $\mathrm{MCH}$ is more rigid than MUA molecules; therefore, MUA surrounded by the rigid short-chain thiols of $\mathrm{MCH}$ is more likely to stand straight on the nanoparticle surface (Fig. 1A) rather than lay flat on the surface of the $\mathrm{Ag}$ nanoparticles, which reduces steric hindrance and allows the MUA to link with IgG more effectively. 
With this approach, we successfully avoided aggregation of nanoparticles and prepared AgMMUA nanoparticles that are stable (size and color of single nanoparticles remain unchanged) in aqueous solution (nanopure water and buffer solution) for months. Although a similar reaction scheme had been used to functionalize the Au surface ${ }^{40}$ and nanoparticles immobilized on the surface ${ }^{18}$, to our knowledge, it has not yet been achieved for $\mathrm{Ag}$ nanoparticles that freely diffuse in the solution. We found that the ratio of MUA to MCH and reaction time was crucial to preventing aggregation of nanoparticles.

NMR spectra show that MUA, MCH and citrate are attached on the surface of Ag nanoparticles with a mole ratio of 1: 3: 30 (Fig. $2 \mathrm{~S}$ in SI). The large and broad chemical shift at $2.5 \mathrm{ppm}$ is from the $-\mathrm{CH}_{2}$-next to thiol of both MUA and $\mathrm{MCH},{ }^{41}$ and citrate adsorbed on the $\mathrm{Ag}$ nanoparticle surface. ${ }^{42}$ Peak broadenings are observed at all chemical shifts of the NMR spectra, indicating that the MUA and MCH are on the surface of Ag nanoparticles, because nanoparticles attached to MUA and MCH slow down the rotational motion of these molecules. 43-45 Furthermore, the gradient of packing density along the functional groups may also contribute to the peak broadening.

Finally, we linked the carboxyl group of AgMMUA with the amine group of $\operatorname{IgG}$ via a peptide bond to prepare single nanoparticle biosensors (AgMMUA-IgG), as illustrated in Figs. 1A \& 1B. By controlling the mole ratio of IgG to AgMMUA nanoparticles at less than one (0.97) during the conjugation reaction, we limit the statistical average conjugation ratio at one $\operatorname{IgG}$ molecule per nanoparticle. The nanoparticle biosensors prepared using covalent conjugation have several advantages over those prepared using electrostatic interaction. They are more stable and the conjugation ratio remains unchanged in buffer solution of various ionic strength and $\mathrm{pH}$, allowing quantitative analysis of individual protein molecules on single living cell surface.

The representative UV-vis absorption spectrum of bulk Ag, AgMMUA and AgMMUA-IgG nanoparticle solution shows a peak wavelength at 393, 400 and $406 \mathrm{~nm}$, respectively, illustrating a red-shift as the surface of $\mathrm{Ag}$ nanoparticles is modified with the functional groups (Fig. 2A). The LSPRS of representative single Ag nanoparticles from these three solutions exhibits a peak wavelength of 450,482 , and $545 \mathrm{~nm}$, respectively, showing a longer wavelength and lower intensity as the surface of $\mathrm{Ag}$ nanoparticles is functionalized with the mixed monolayer of MUA and MCH, and linked with IgG (Fig. 2B). The histograms of the different colors (LSPRS) of individual nanoparticles of the three solutions in Fig. $2 \mathrm{C}$ shows that $\mathrm{Ag}$ nanoparticles in nanopure water contains blue (88\%) and green (12\%) nanoparticles; AgMMUA nanoparticles in nanopure water includes the light green (82\%) and yellow green (19\%) nanoparticles; and AgMMUA-IgG nanoparticles in PBS buffer has dark green (75\%), yellow (11\%), and white (14\%) nanoparticles.

As described by Mie theory 46 and demonstrated by our previous studies $13,15,16$, the LSPRS and scattering intensity of single $\mathrm{Ag}$ nanoparticles highly depend on its size, shape, surface properties and surrounding environments. The color distribution of individual nanoparticles further illustrates that the functional groups on the surface of $\mathrm{Ag}$ nanoparticles lead to changes of the optical properties of individual nanoparticles, and the red shift of their LSPRS. The white color of nanoparticles observed in the AgMMUA-IgG solution is most likely attributable to the cross-linking of nanoparticles, leading to larger nanoparticles, which can be removed via centrifugation.

\section{Characterization of Biological Activity of Single Nanoparticle Biosensors}

The primary challenge of preparing effective nanoparticle biosensors, especially by covalent conjugation of protein molecules (IgG, ligand) with nanoparticles, is to retain the biological activities of those biomolecules attached on the surface of nanoparticles. To characterize the 
biological activity of AgMMUA-IgG, we measured their binding affinity with PrA in buffer solution, and compared their binding constant with that of IgG-PrA in solution.

The results in Fig. 3 illustrate that the absorbance of AgMMUA-IgG nanoparticles decreases and reaches a constant value, indicating that AgMMUA-IgG nanoparticles bind with PrA and reach binding equilibrium. It is well known that $\operatorname{PrA}$ (a receptor) displays 3-4 binding sites for the Fc portion of rabbit $\mathrm{IgG}^{47-49}$, which allows one PrA molecule to bind with multiple AgMMUA-IgG nanoparticles, leading to the precipitation of bound IgG-PrA. ${ }^{49}$ The peak wavelength of the spectra remains constant over time (Fig. 3A), suggesting that AgMMUA$\operatorname{IgG}-\operatorname{PrA}$ nanoparticles did not contribute significantly to the absorbance and indicating that cross-linked AgMMUA-IgG-PrA nanoparticles precipitate from solution. Otherwise, we would observe a red shift of peak wavelength if the cross-linked larger AgMMUA-IgGPrA nanoparticles remained suspended in the solution. The extinction coefficient (molar absorptivity, $\varepsilon_{1}$ ) of AgMMA-IgG calculated from the absorption spectra using the BeerLambert law is $2.6 \times 10^{8} \mathrm{M}^{-1} \mathrm{~cm}^{-1}$.

Plot of peak absorbance subtracted from baseline versus time in Fig. 3 B \& C demonstrates a nearly first-order reaction as illustrated below:

$$
\text { AgMMUA-IgG+PrA } \rightleftharpoons \text { AgMMUA-IgG-PrA }
$$

Since the PrA molar concentration is 100 times higher than that of AgMMUA-IgG, we assume the PrA concentration remains constant over the entire reaction. Thus, a second-order (or multiple-order) reaction can be treated as a first-order reaction. Using the change of AgMMUAIgG absorbance resulting from its binding with PrA, we calculate the amount of AgMMUA$\operatorname{IgG}$ nanoparticles $(0.14 \mathrm{nM})$ that bound with $\operatorname{PrA}$ and the amount of AgMMUA-IgG-PrA $(0.14$ $\mathrm{nM})$ that is generated, showing equilibrium concentrations of AgMMUA-IgG $(0.96 \mathrm{nM}), \operatorname{PrA}$ $(99.86 \mathrm{nM})$ and $\mathrm{AgMMUA}-\operatorname{IgG}-\operatorname{PrA}(0.14 \mathrm{nM})$, and the equilibrium binding constant (affinity, $\mathrm{K}_{\mathrm{b}}$ ) as $1.5 \times 10^{6} \mathrm{M}^{-1}$.

We further determined the binding association rate constant $\left(\mathrm{k}_{\mathrm{a}}=1.2 \times 10^{2} \mathrm{M}^{-1} \mathrm{~s}^{-1}\right)$ and dissociation rate constant $\left(\mathrm{k}_{\mathrm{d}}=5.4 \times 10^{-5} \mathrm{~s}^{-1}\right)$ using the slope of Fig. $3 \mathrm{C}$ and by matching simulation data with the experimental data in Fig. $3 \mathrm{~B}$, respectively. The detailed calculation is shown in SI. Using this approach, we can calculate the binding affinity constant $\left(\mathrm{K}_{\mathrm{b}}=\mathrm{k}_{\mathrm{a}} / \mathrm{k}^{\mathrm{d}}=\right.$ $2.2 \times 10^{6} \mathrm{M}^{-1}$ ), which agrees well with the $\mathrm{K}_{\mathrm{b}}$ directly calculated using equilibrium concentrations. The experiments were repeated three times and the average of $\mathrm{K}_{\mathrm{b}},(1.9 \pm 0.1)$ $\times 10^{6} \mathrm{M}^{-1}$, determined by both methods, agrees well with those observed in solution $\left(3 \times 10^{6}\right.$ $\mathrm{M}^{-1}$ ) and reported in the literature ${ }^{50}$. Thus, a primary biological activity of $\mathrm{IgG}$ conjugated with nanoparticles is preserved, allowing AgMMUA-IgG nanoparticles to be used to image and characterize individual receptor molecules on single living cells.

\section{Imaging and Sensing of Individual Receptor Molecules on Single Living Cells}

We anchored the T-ZZ onto the membrane of living cells to create the desired low coverage of individual ZZ molecules $\left(0.21-0.37\right.$ molecules $\left./ \mu \mathrm{m}^{2}\right)$ on living cells ${ }^{28-30}$, which were detected by single AgMMUA-IgG nanoparticles and imaged in real-time using SNOMS (Fig. 4). Since the mole ratio of $\operatorname{IgG}$ to AgMMUA nanoparticles is 0.97, a single $\operatorname{IgG}$ molecule is statistically conjugated with a single AgMMUA nanoparticle. Although multiple IgG molecules may be present in a single AgMMU-IgG nanoparticle, the low coverage of T-ZZ molecules on the surface of single living cells, and the low concentration of AgMMUA-IgG nanoparticles greatly reduces the possibility of having more than one T-ZZ molecule bound with a single AgMMUA-IgG nanoparticle, because, at such low coverage (0.21-0.37 molecules $\left./ \mu \mathrm{m}^{2}\right)$, it is extremely unlikely to have two neighboring T-ZZ molecules within the proximity of a single AgMMUA-IgG nanoparticle ( $15 \mathrm{~nm}$ in diameter). If two T-ZZ molecules were located within a cross sectional area of a single nanoparticle $\left(2.3 \times 10^{-4} \mu \mathrm{m}^{2}\right)$, 
the coverage of T-ZZ on a single living cell surface would be 8.7$\} 10^{4}$ molecule $/ \mu \mathrm{m}^{2}$. For those nanoparticles that are not conjugated with IgG, they will not bind with T-ZZ, which will not be detected on cell surface. Thus, no washing step is needed for this assay, and the possible small variation of conjugation ratio of nanoparticles with IgG will not affect SMD of individual receptors on single living cells.

Thus, by controlling a low conjugation ratio of $\operatorname{IgG}$ with AgMMUA nanoparticles and low coverage of T-ZZ on living cell surface, we ensure that a SMD scheme is appropriately applied for the reaction described below:

AgMMUA-IgG+Cell-T-ZZ $\rightleftharpoons$ AgMMUA-IgG-ZZ-T-Cell

Fibroblast cells are highly adhesive cells and were directly cultured on coverslips. Thus, the cells would not move during the experiments. Diffusion of the attached T-ZZ molecules is confined within the cell membrane, which is orders of magnitudes slower than the Brownian motion of single nanoparticles in solution. ${ }^{16,17,51}$ Therefore, once AgMMUA-IgG nanoparticles bind with T-ZZ on the cell surface, the diffusion of the nanoparticles is negligible in comparison with the free Brownian motion of individual nanoparticles in the solution, showing that the bound AgMMUA-IgG nanoparticles become bright spots shrunk to the resolution limit of the CCD with a 2-pixel diameter. This unique feature allows us to avoid the washing step and directly image the number of individual T-ZZ molecules bound with AgMMUA-IgG nanoparticles on the surface of cells. We also acquired sequence images of living cells incubated with AgMMUA-IgG over time, and did not observe significant diffusion of T-ZZ bound with AgMMUA-IgG on living cells. We also used the scattering intensity of individual nanoparticles to determine whether the clusters of T-ZZ (more than a single nanoparticle) were present within the spatial resolution of CCD camera, showing no evidence of aggregation of T-ZZ.

Interestingly, we observed a red shift of the LSPRS of AgMMUA-IgG nanoparticles as they bound with T-ZZ on living cells, showing more orange and red nanoparticles (Fig. 4\&Fig. 5), which may be attributable to the change of the surface properties and dielectric constant of embedded medium of nanoparticles. This interesting phenomenon offers an additional feature, allowing us to distinguish bound and unbound AgMMUA-IgG nanoparticles.

To measure their binding affinity and determine the dependence of binding kinetics on concentration of AgMMUA-IgG nanoparticles, we prepared one surface coverage of T-ZZ molecules $\left(0.37\right.$ molecules $\left./ \mu^{2}\right)$ on living cells and used four concentrations $(1.39,2.78,5.56$, and $11.12 \mathrm{nM}$ ) of AgMMU-IgG nanoparticles (Table I-Table II in SI). Although the binding dissociation constant $\left(\mathrm{K}_{\mathrm{D}}\right)$ of IgG with T-ZZ on the living cells has not yet been reported, the $\mathrm{K}_{\mathrm{D}}$ of T-ZZ with IgG on phospholipids (not on living cell membrane) was estimated as $43 \mathrm{nM}$ by previous bulk measurement. 28,52 Thus, the selected concentrations of AgMMUA-IgG nanoparticles mimic the ligand ( $\operatorname{IgG})$ concentrations well below its $\mathrm{K}_{\mathrm{D}}$.

Using CCD microarray, we were able to image the distribution and binding reaction of T-ZZ molecules on several living cells simultaneously (Fig. 4). Representative cells selected from the full-frame images similar to those in Fig. 4 are illustrated in Fig. 5A, showing the concentration and time dependence of AgMMUA-IgG nanoparticles binding with T-ZZ on living cells. At the same concentration of AgMMUA-IgG, more AgMMUA-IgG nanoparticles bind with T-ZZ molecules on living cells as incubation time increases from 0 to $180 \mathrm{~min}$ (the vertical column of Fig. 5A), demonstrating time-dependence and real-time monitoring of the binding reaction on living cells. At a given incubation time, as AgMMUA-IgG concentration increases, more AgMMUA-IgG nanoparticles bind with T-ZZ molecules on the cells (the horizontal row of Fig. 5A), showing concentration dependence. 
Using the same approach, we investigated the dependence of binding kinetics on the coverage of T-ZZ on living cells. We used a single concentration of AgMMUA-IgG nanoparticles (2.78 $\mathrm{nM}$ ) to detect individual T-ZZ molecules on living cells, which were present with two different coverages of T-ZZ $\left(0.21\right.$ and 0.37 molecules $\left./ \mu \mathrm{m}^{2}\right)$. We observed more AgMMUA-IgG nanoparticles bound with T-ZZ on living cells as incubation time increased (vertical column of Fig. 5B). At the given incubation time, more AgMMUA-IgG nanoparticles bound with T$\mathrm{ZZ}$ on living cells with the higher coverage of T-ZZ (horizontal row of Fig. 5B), showing the dependence of binding reaction rate on the coverage of $\mathrm{T}-\mathrm{ZZ}$ on cell surface.

To determine possible non-specific interactions of AgMMUA-IgG nanoparticles with living cell membrane, three blank control experiments were performed, by incubating $11.12 \mathrm{nM}$ AgMMUA (not yet conjugated with IgG) with living cells attached with T-ZZ prepared as described in Figs. 5 A \& B, and by incubating $11.12 \mathrm{nM} \mathrm{AgMMUA-IgG} \mathrm{nanoparticles} \mathrm{(the}$ highest concentration used in Fig. 5A) with living cells that were not attached with T-ZZ molecules, showing no significant number of bound AgMMUA-IgG nanoparticles on living cells (Fig. 5C).

The viability of the cells during each experiment was monitored using a Trypan Blue cell viability assay, showing more than $90 \%$ of cells remained alive for the entire experimental duration from treatment with $\mathrm{T}-\mathrm{ZZ}$ at $\mathrm{pH} 4.8$ for $45 \mathrm{~min}$, rinsing with the buffer at $\mathrm{pH} 7.4$, and imaging in the microchannel for $1.5 \mathrm{hr}$.

Plots of the number of bound AgMMUA-IgG nanoparticles with T-ZZ on living cells versus reaction time for the study of dependence of AgMMUA-IgG concentration (Fig. 5A), T-ZZ coverage on cell surface (Fig. 5B), and blank control experiments (Fig. 5C), are presented in Figs $6 \mathrm{~A}, 6 \mathrm{~B}$, and $6 \mathrm{C}$, respectively. The results further illustrate that binding kinetics depend on ligand concentrations (AgMMUA-IgG) and the coverage of model receptors (T-ZZ) on the cell surface. The control experiments show insignificant non-specific interaction of AgMMUA-IgG nanoparticles with cell membrane.

We determined the binding association $\left(k_{1}\right)$ and dissociation $\left(k_{-1}\right)$ rate constants, and binding affinity constant $\left(\mathrm{K}_{\mathrm{B}}\right)$ at $(9.0 \pm 2.6) \times 10^{3} \mathrm{M}^{-1} \mathrm{~s}^{-1},(3.0 \pm 0.4) \times 10^{-4} \mathrm{~s}^{-1}$, and $(3.0 \pm 0.6) \times$ $10^{7} \mathrm{M}^{-1}$, respectively. The $\mathrm{K}_{\mathrm{B}}$ agrees well with those reported from bulk measurement. ${ }^{28}$, $52 \mathrm{We}$ also determined the number of T-ZZ molecules on living cells prepared as described in Figs. 5A \& 5B, showing 4640 and 2687 molecules of T-ZZ on the surface of 40 living cells, respectively. Thus, on average, there are 119 and 67 molecules per cell, which creates coverage of 0.37 and 0.21 molecules $/ \mu \mathrm{m}^{2}$, respectively. The calculation details are described in Table I-Table II of SI.

At higher AgMMUA-IgG nanoparticle concentrations (2.78, 5.56 and $11.12 \mathrm{nM}$ ), we observed a decrease in the number of bound nanoparticles after the binding reaction reached equilibrium at 80-100 min. This interesting phenomenon was not observed at the lowest concentration (1.39 nM) of AgMMUA-IgG (Fig. 6A: a), nor at the lower coverage of T-ZZ (Fig. 6B: a), suggesting that, as more AgMMUA-IgG nanoparticles bound with T-ZZ on living cell surface, it may become harder to distinguish two nearby nanoparticles within the spatial resolution of the CCD camera (single pixel, $65 \mathrm{~nm}$ ) using optical microscopy, or that the higher concentrations of bound T-ZZ may lead to dissociation. The results also suggest that a high coverage of bound nanoparticles on living cells may promote their tendency to aggregate. Effort has been made to distinguish multiple nanoparticles from a single nanoparticle within the spatial resolution of CCD camera (1-2 pixel) using the scattering intensity of single nanoparticles. However, we found no evidence that multiple nanoparticles were present within the spatial limit of the CCD camera. Thus, the observation may be attributable to the 
dissociation of AgMMUA-IgG from T-ZZ. Studies are under way to further characterize the mechanism.

The binding rates of AgMMUA-IgG nanoparticles $(1.39,2.78,5.56$ and $11.12 \mathrm{nM})$ with T-ZZ on living cells were calculated from the slopes of Fig. 6A (a-d) within the first $60 \mathrm{~min}$ before reaching equilibrium, showing 3.0, 5.3, 20 and 27 molecules/min, respectively. A plot of the binding rates versus concentration of AgMMUA-IgG shows the high dependence of binding rates on concentration (Fig. 7A). Using the same approach, we found that the binding rate for $2.78 \mathrm{nM}$ of AgMMUA-IgG nanoparticles with two different coverages of T-ZZ ( 0.21 and 0.37 molecules $/ \mu \mathrm{m}^{2}$ ) in Fig. 6B is 2.3 and 5.3 molecule/min, respectively, showing the dependence of binding rate with the coverage of T-ZZ on living cells.

We further analyzed the bound AgMMUA-IgG nanoparticles versus the concentration at binding equilibrium (80-120 min in Fig. 6A). Plots of fraction $(f)$ of bound T-ZZ on living cells versus concentration of AgMMUA-IgG (isotherms in Fig. 7B) further indicate that we detected T-ZZ molecules on living cells below their binding dissociation constant. Due to the limit of spatial resolution, higher concentrations of AgMMUA-IgG were not used to detect higher coverage of bound T-ZZ on living cells. Nevertheless, we are able to calculate $\mathrm{K}_{\mathrm{B}}$ as $(4.8 \pm 2.0) \times 10^{7} \mathrm{M}^{-} 1$ from the isotherms in Fig. $7 \mathrm{~B}$, which is similar to those calculated from Fig. 6A. The isotherms show a sigmoidal shape, suggesting that the binding reaction is cooperative, which means that T-ZZ molecules on the surface of living cells are not completely independent. In other words, the binding reaction of AgMMUA-IgG nanoparticles with individual T-ZZ molecules becomes more favorable in the presence of surrounding bound T$\mathrm{ZZ}$ molecules. A plausible explanation would be that the presence of T-ZZ molecules bound with AgMMUA-IgG nanoparticles on cell surface made it easier for other nanoparticles to dock onto the cell surface. Similar phenomena where bound nanoparticles on the cell surface serve as nucleation sites to help more nanoparticles to dock on the surface were also observed in our previous study. 15

Taken together, our results show that single nanoparticle biosensors can be used to map lowcoverage single receptor molecules (less than $\sim 50$ receptors per cell) on single living cells in real-time, which is what we aim for. Using optical microscopy, single nanoparticle biosensors are not suitable for detecting high coverage of protein molecules on single living cells, because of limitation of optical resolution. Using TEM, one can expect to map high coverage of protein molecules on cell surface using single nanoparticle biosensors, but TEM cannot offer real-time kinetic measurements on living cells.

\section{Summary}

In summary, this study contributes the following research advances: (i) design and synthesis of single $\mathrm{Ag}$ nanoparticle biosensors that resist their aggregation in the buffer solution, retain their photostability, and preserve the bioactivity of conjugated protein molecules; (ii) utilizing high QY of Rayleigh scattering of single Ag nanoparticle biosensors and a new detection scheme (SNOMS), we effectively avoid auto-fluorescence of cells and photo-instability of fluorescent probes, and achieve unprecedented sensitivity to quantitatively detect, map and characterize binding affinity and kinetics of single receptor molecules on single living cells in real time over hrs; and (iii) using the unique properties of $\mathrm{T}$ domain and protein engineering approach, we anchor functional receptors on living cell surface, generating a new, clean model system for validation and calibration of tools for probing single receptor molecules on single living cells in real time. One can now use these tools for quantitative molecular imaging of single protein molecules on single living cells for any desired period of time, offering new possibilities for monitoring cascades of biochemical reactions in real time. Work is in progress to use single nanoparticle biosensors and related detection scheme developed in this study to 
quantitatively analyze single ligand (e.g., hIL-2) and single receptor molecules (e.g., hIL-2R) on single living cells for effective characterization of anticancer vaccines and for better understanding of their biological functions.

\section{Supplementary Material}

Refer to Web version on PubMed Central for supplementary material.

\section{Acknowledgements}

We thank CharFac of University of Minnesota (a NNIN site funded by NSF) for their assistance to characterize Ag nanoparticles using HR-TEM. This work is supported in part by NSF-NIRT (BES 0507036), NIH (R01 GM076440), Old Dominion University, and CEA (Gillet). P. Nallathamby is grateful for the support of Dominion Scholar Fellowship. The Gillet group at CEA constructed T-ZZ. All other work was carried out in the Xu lab at ODU.

\section{References}

1. Gurevich KG, Agutter PS, Wheatley DN. Cell Signal 2003;15:447-453. [PubMed: 12618219]

2. Williamson SA, Knight RA, Lightman SL, Hobbs JR. Brain Behav. Immun 1987;1:329-335. [PubMed: 2898956]

3. Williamson SA, Knight RA, Lightman SL, Hobbs JR. Immunology 1988;65:47-51. [PubMed: 2846433]

4. Dower SK, Kronheim SR, Hopp TP, Cantrell M, Deeley M, Gillis S, Henney CS, Urdal DL. Nature 1986;324:266-268. [PubMed: 2946959]

5. Weiss S. Science 1999;283:1676-1683. [PubMed: 10073925]

6. Janshoff A, Neitzert M, Oberdorfer Y, Fuchs H. Angew Chem Int Ed Engl 2000;39:3212-3237. [PubMed: 11028062]

7. Beesley, JE. Oxford University Press, Royal Microscopy Society; 1989. p. 25

8. Manweiler K, Hohenberg H, Bohn W, Rutter G. J. Microsc 1982;126:145-149. [PubMed: 7086887]

9. Haes AJ, Van Duyne RP. J. Am. Chem. Soc 2002;124:10596-10604. [PubMed: 12197762]

10. Lyon LA, Musick MD, Natan M. J. Anal. Chem 1998;70:5177-5183.

11. Nam JM, Thaxton CS, Mirkin CA. Science 2003;301:1884-1886. [PubMed: 14512622]

12. Schultz S, Smith DR, Mock JJ, Schultz DA. Proc. Natl. Acad. Sci. U S A 2000;97:996-1001. [PubMed: 10655473]

13. Kyriacou SV, Brownlow WJ, Xu XH. Biochemistry 2004;43:140-147. [PubMed: 14705939]

14. Sandhu KK, McIntosh CM, Simard JM, Smith SW, Rotello VM. Bioconjug. Chem 2002;13:3-6. [PubMed: 11792172]

15. Xu XHN, Chen J, Jeffers RB, Kyriacou SV. Nano Letters 2002;2:175-182.

16. Xu XHN, Brownlow WJ, Kyriacou SV, Wan Q, Viola JJ. Biochemistry 2004;43:10400-10413. [PubMed: 15301539]

17. Xu, X-HN.; Song, Y.; Nallathamby, PD. Probing membrane transport of single live cells using single molecule detection and single nanoparticle assay. New Jersey: Wiley; 2007.

18. Haes AJ, Zhao J, Zou S, Own CS, Marks LD, Schatz GC, Van Duyne RP. J. Phys. Chem. B 2005;109:11158-11162. [PubMed: 16852361]

19. Ambrose WP, Goodwin PM, Jett JH, Van Orden A, Werner JH, Keller RA. Chem. Rev 1999;99:2929_ 2956. [PubMed: 11749506]

20. Nie S, Zare RN. Annu. Rev. Biophys. Biomol. Struct 1997;26:567-596. [PubMed: 9241430]

21. Xu XH, Yeung ES. Science 1997;275:1106-1109. [PubMed: 9027307]

22. Xu XHN, Yeung ES. Science 1998;281:1650-1653. [PubMed: 9733506]

23. Xu XHN, Jeffers RB, Gao J, Logan B. Analyst 2001;126:1285-1292. [PubMed: 11534594]

24. Byassee TA, Chan WC, Nie S. Anal. Chem 2000;72:5606-5611. [PubMed: 11101238]

25. Xu XHN, Brownlow WJ, Huang S, Chen J. Biochem. Biophys. Res. Commun 2003;305:79-86.

[PubMed: 12732199] 
26. Yu J, Xiao J, Ren X, Lao K, Xie X. Science 2006;311:1600-1603. [PubMed: 16543458]

27. Kyriacou SV, Nowak ME, Brownlow WJ, Xu XH. J Biomed Opt 2002;7:576-586. [PubMed: 12421124]

28. Chenal A, Savarin P, Nizard P, Guillain F, Gillet D, Forge V. J Biol Chem 2002;277:43425-43432. [PubMed: 12193591]

29. Nizard P, Chenal A, Beaumelle B, Fourcade A, Gillet D. Protein Eng 2001;14:439-446. [PubMed: 11477224]

30. Nizard P, Liger D, Gaillard C, Gillet D. FEBS Lett 1998;433:83-88. [PubMed: 9738938]

31. Oh KJ, Zhan H, Cui C, Hideg K, Collier RJ, Hubbell WL. Science 1996;273:810-812. [PubMed: 8670424]

32. Montagner C, Perier A, Pichard S, Vernier G, Ménez A, Gillet D, Forge V, Chenal A. Biochemistry 2007;46:1878-1887. [PubMed: 17249698]

33. Nizard P, Gross DA, Babon A, Chenal A, Beaumelle B, Kosmatopoulos K, Gillet D. J Immunother 2003;26:63-71. [PubMed: 12514430]

34. Choe S, Bennett MJ, Fujii G, Curmi PM, Kantardjieff KA, Collier RJ, Eisenberg D. Nature 1992;357:216-222. [PubMed: 1589020]

35. Xu XHN, Huang S, Brownlow W, Salatia K, Jeffers R. J. Phys. Chem. B 2004;108:15543-15551.

36. Xu XHN, Wan Q, Kyriacou SV, Brownlow WJ, Nowak ME. Biochem Biophys Res Commun 2003;305:941-949. [PubMed: 12767921]

37. Li X, Xu W, Zhang J, Jia H, Yang B, Zhao B, Li B, Ozaki Y. Langmuir 2003;19:4285-4290.

38. Panigrahi S, Praharaj S, Basu S, Ghosh SK, Jana S, Pande S, Vo-Dinh T, Jiang H, Pal T. J Phys Chem B Condens Matter Mater Surf Interfaces Biophys 2006;110:13436-13444. [PubMed: 16821868]

39. Yamamoto M, Kashiwagi Y, Nakamoto M. Langmuir 2006;22:8581-8586. [PubMed: 16981779]

40. Laibinis PE, Hickman JJ, Wrighton MS, Whitesides GM. Science 1989;245:845-847. [PubMed: 17773361]

41. Lee JK, Yoon TJ, Chung YK. Chemical Communications 2001:1164-1165.

42. Wawer I, Pisklak M, Chilmonczyk Z. J Pharm Biomed Anal 2005;38:865-870. [PubMed: 16087048]

43. Hasan M, Bethell D, Brust M. J. Am. Chem. Soc 2002;124:1132-1133. [PubMed: 11841257]

44. Ingram RS, Hostetler MJ, Murray RW. J. Am. Chem. Soc 1997;119:9175-9178.

45. Kohlmann O, Steinmetz WE, Mao XA, Wuelfing WP, Templeton AC, Murray RW, Johnson CS. J. Phys. Chem. B 2001;105:8801-8809.

46. Mie G, Beiträg G. Ann Phys 1908;25:377-445.

47. Ghetie V, Fabricius HA, Nilsson K, Sjoquist J. Immunology 1974;26(6):1081-1091. [PubMed: 4604795]

48. Hjelm H, Sjodahl J, Sjoquist J. Eur J Biochem 1975;57(2):395-403. [PubMed: 1175649]

49. Langone, JJ. Protein A of Staphylococcus aureus and Related Immunoglobulin Receptors Produced by Streptococci and Pneumonococci. New York: Academic Press; 1982.

50. Lancet D, Isenman D, Sjödahl J, Sjöquist J, Pecht I. Biochem. Biophys. Res. Commun 1978;85:608614. [PubMed: 83866]

51. Tinoco, I.; Sauer, K.; Wang, J.; Puglisi, JD. Physical Chemistry-Principles and Applications in Biological Sciences. Prentice Hall; 2002. p. 315-387.

52. Jansson B, Uhlen M, Nygren PA. FEMS Immunol Med Microbiol 1998;20:69-78. [PubMed: 9514577] 
A

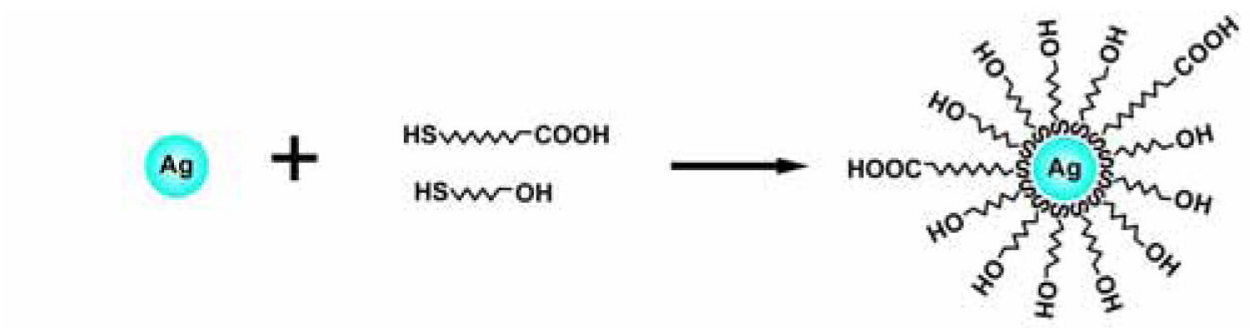

B
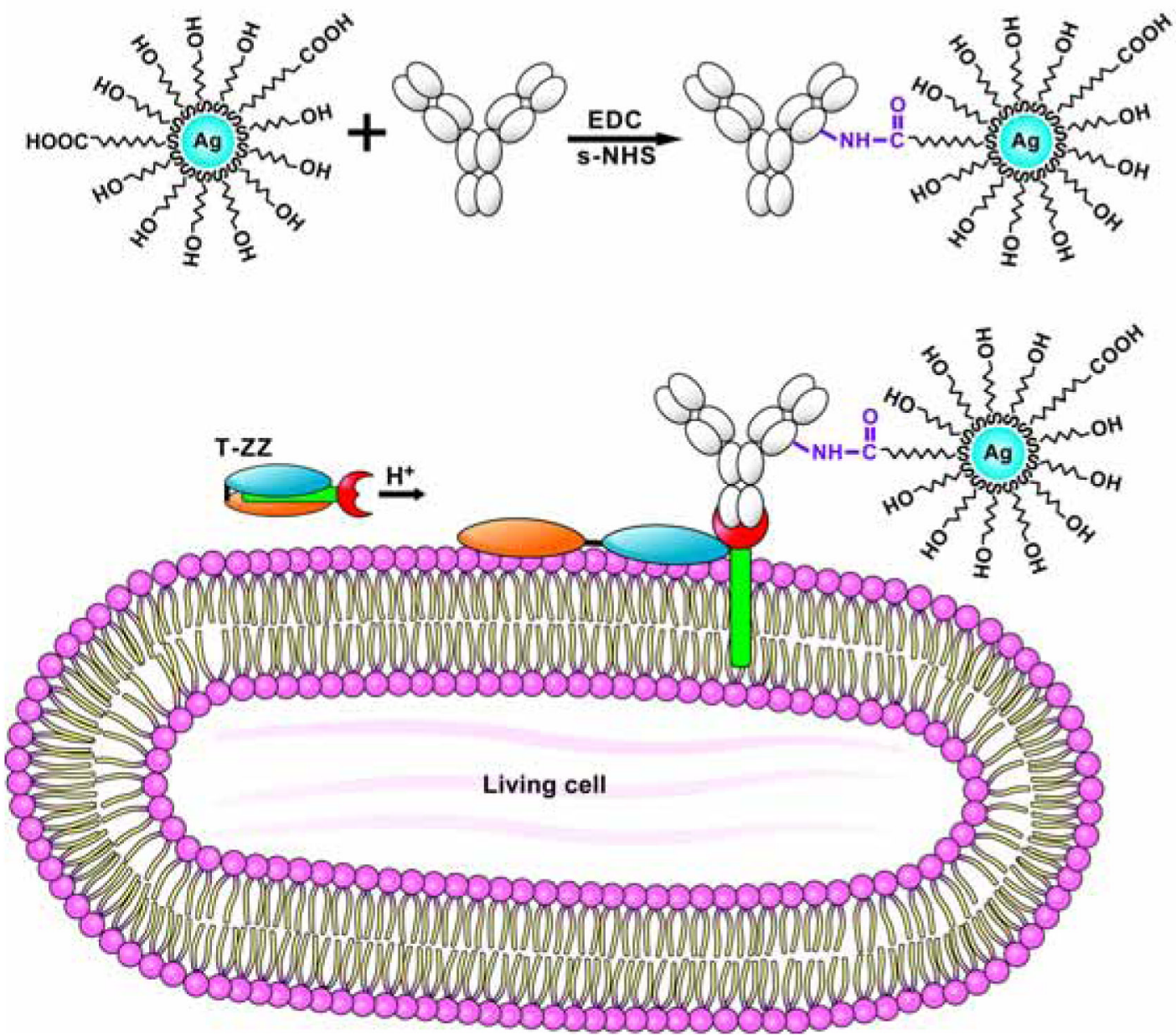

Figure 1.

Schematic illustration of preparation of single nanoparticle biosensors (AgMMUA-IgG) and using the biosensors to image and detect single T-ZZ molecules on single living cells: (A) functionalizing Ag nanoparticles with a mix monolayer of MUA and MCH (1: 3 mole ratio) by strong interaction of $\mathrm{Ag}$ with thiol group of MUA and $\mathrm{MCH}$; (B) covalently linking AgMMUA nanoparticles with IgG via a peptide bond using EDC and sulfo-NHS as mediators, to prepare AgMMUA-IgG nanoparticles; $(\mathbf{C})$ attaching T-ZZ onto living cells by adjusting $\mathrm{pH}$ to 4.8 , and detecting single T-ZZ molecules on single living cells using single nanoparticle biosensors. 

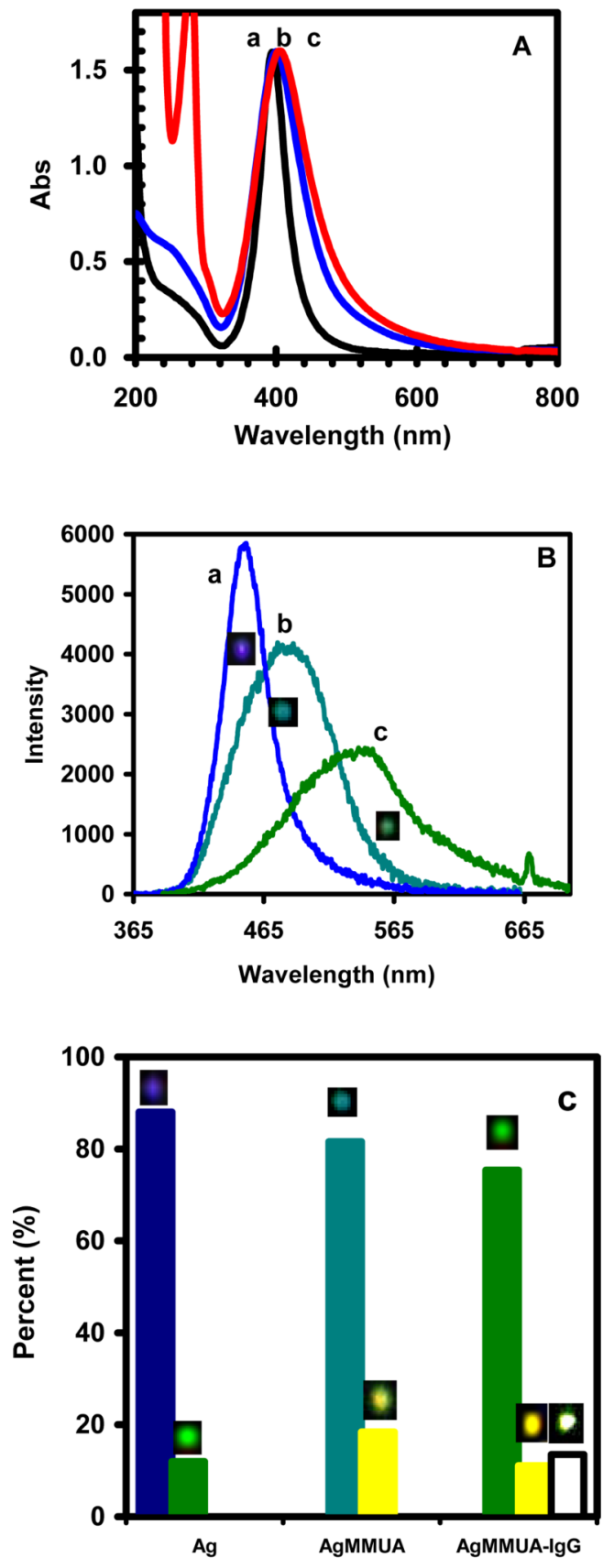

Figure 2.

Characterization of optical properties of Ag, AgMMUA and AgMMUA-IgG nanoparticles: (A) representative UV-vis spectra of (a) $3.28 \mathrm{nM} \mathrm{Ag}$ and (b) $4.33 \mathrm{nM} \mathrm{AgMMUA} \mathrm{nanoparticles}$ in nanopure water and (c) $5.24 \mathrm{nM}$ AgMMUA-IgG nanoparticles in PBS buffer; (B) LSPR spectra of the representative single Ag, AgMMUA and AgMMUA-IgG nanoparticle in the solution of (A); (C) Histograms of color distributions of single Ag, AgMMUA and AgMMUA$\mathrm{IgG}$ nanoparticles in the solution of (A). 

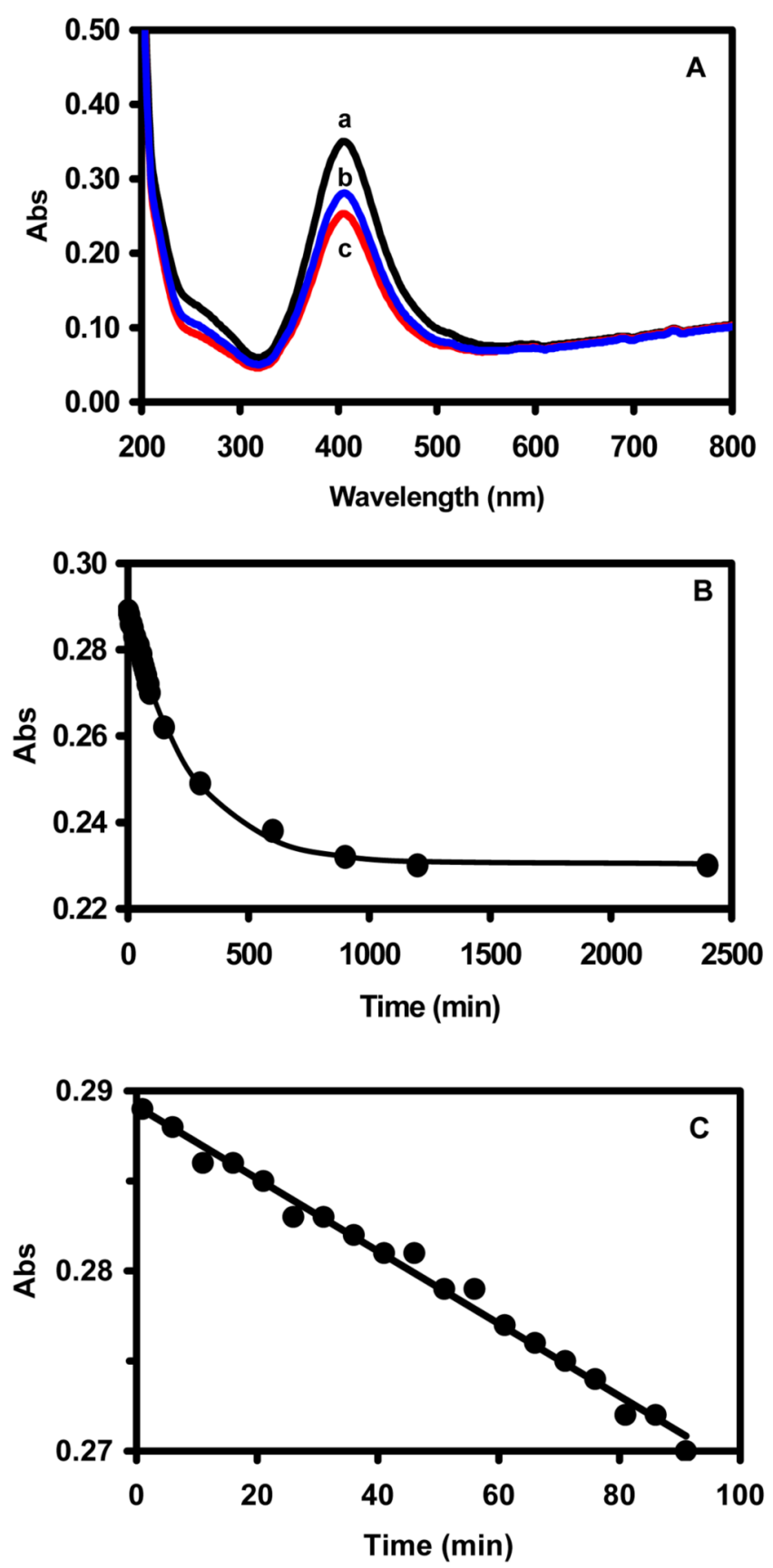

Figure 3.

Characterization of biological activity of AgMMUA-IgG nanoparticles: (A) UV-vis spectra of $250 \mu \mathrm{L}$ of $1.1 \mathrm{nM}$ AgMMUA-IgG in the PBS buffer solution (a) before, at (b) 5 min and (c) 24 hours after adding $1.0 \mu \mathrm{L}$ of $25 \mu \mathrm{M}$ PrA, showing a decrease in absorbance; (B) Plot of peak absorbance of the solution corrected with baseline in (A) versus the incubation time, showing the exponential decay: points are experimental measurements and solid line is generated by fitting the data points with a equation, Abs $=0.23+0.059 \times \mathrm{e}(-0.0039 * \mathrm{t})$ and $\mathrm{R}^{2}$ $=1.0 ;$ (C) Plots of peak absorbance in (B) versus the incubation time at the early reaction time (0-90 $\mathrm{min})$, showing a linearity with a slope $=-2.0 \times 10^{-4} \mathrm{~min}^{-1}$, intercept $=0.29$ and $\mathrm{R}^{2}=$ 
0.99. $\mathrm{R}^{2}$ in (B) and (C) is the multiple correlation coefficient and linear regression coefficient of determination, respectively. 


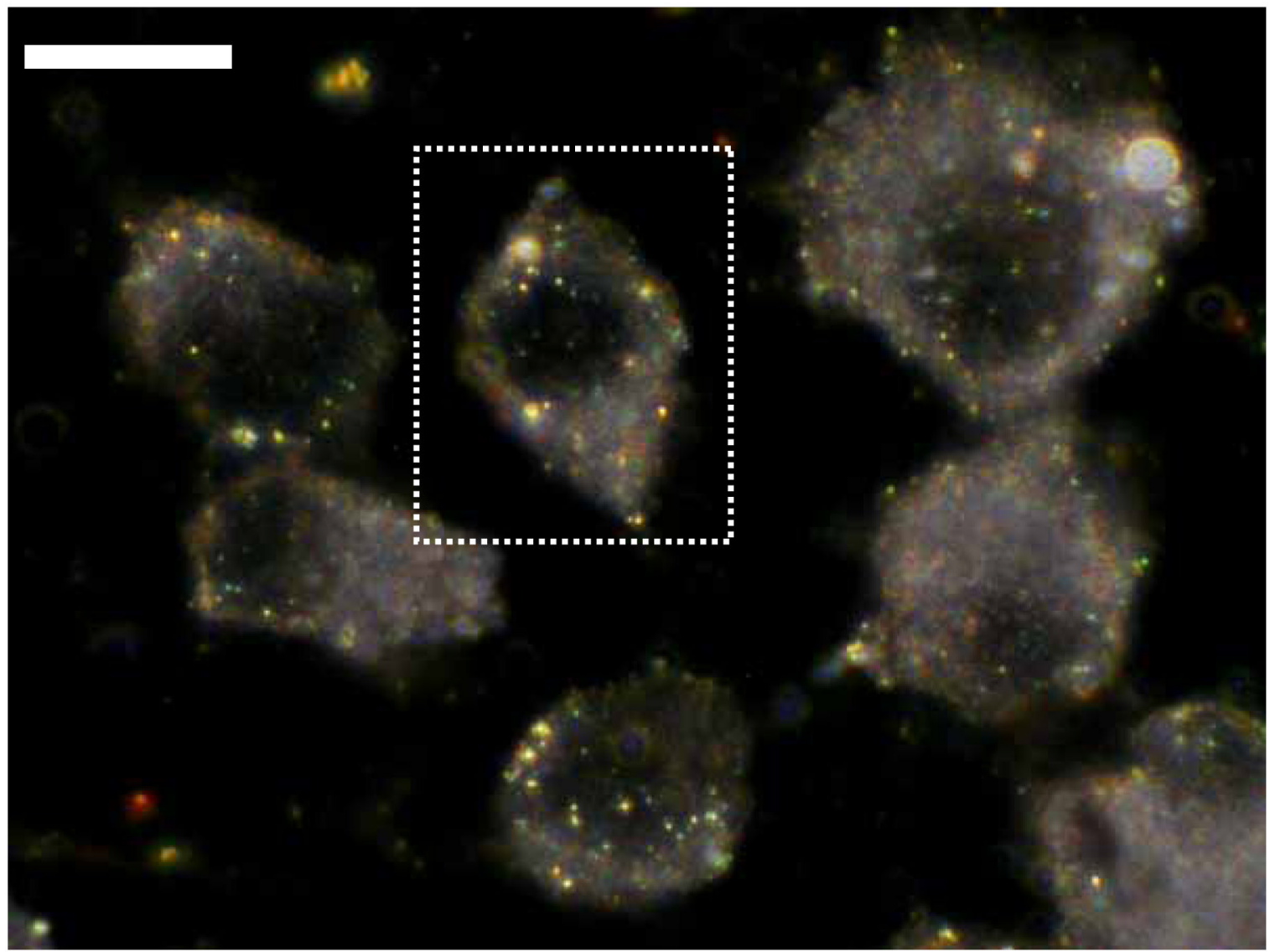

Figure 4.

Imaging and sensing of single T-ZZ molecules on single living cells using single AgMMUAIgG nanoparticle biosensors. The living cells attached with T-ZZ $\left(0.37\right.$ molecules $\left./ \mu \mathrm{m}^{2}\right)$ were incubated with $5.56 \mathrm{nM}$ AgMMUA-IgG nanoparticles and imaged using our SNOMS imaging system. The scale bar $=10 \mu \mathrm{m}$. 
A

(a) 1.39

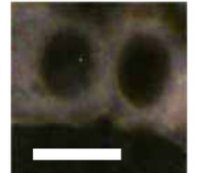

(b) 2.78

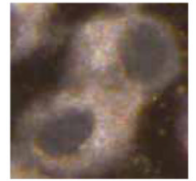

(c) 5.56
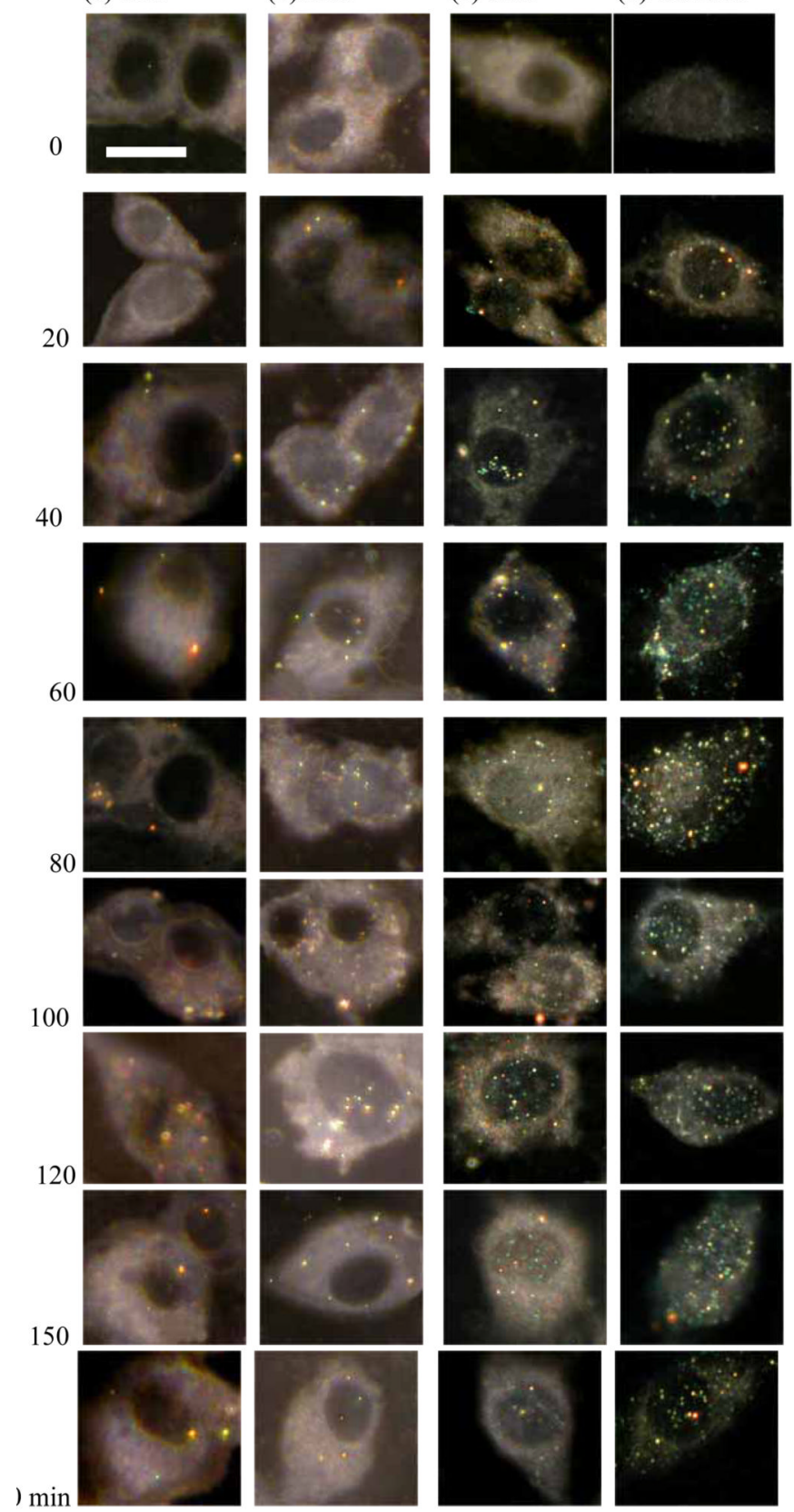


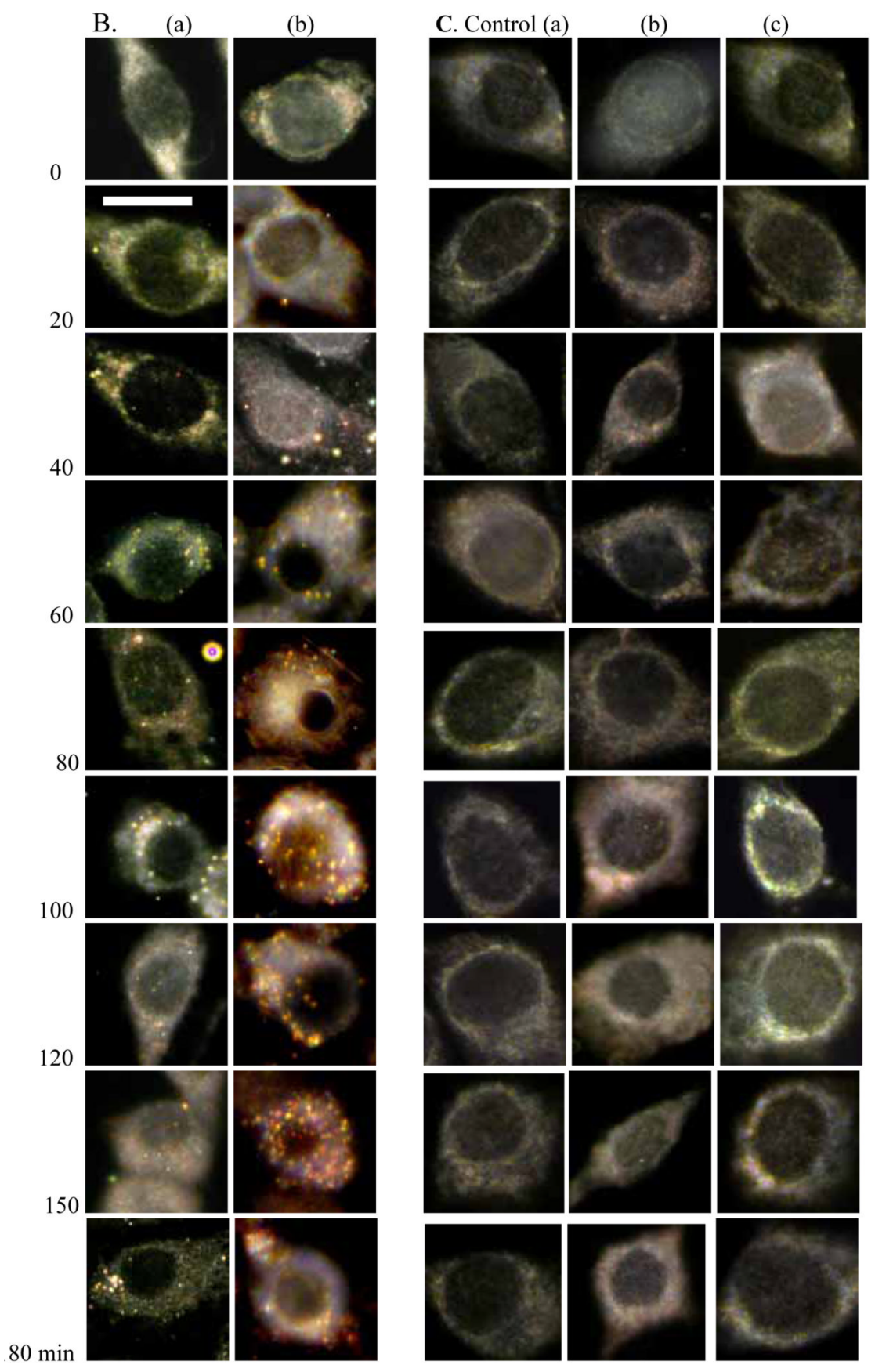

Figure 5.

Imaging and characterization of the concentration dependence of binding kinetics of AgMMUA-IgG with T-ZZ on single living cells at the single-molecule resolution. Sequence optical images of representative cells selected from at least 120 cells at each given reaction time ( $0-180 \mathrm{~min})$ and concentration: (A) coverage of T-ZZ on living cells $(0.37$ molecules/ $\mu \mathrm{m}^{2}$ ) remains constant, which are incubated with (a) 1.39 ; (b) 2.78 ; (c) 5.56 ; (d) $11.12 \mathrm{nM}$ of AgMMUA-IgG nanoparticles, showing the time- and concentration- dependence; (B) AgMMUA-IgG nanoparticle concentration remains constant at $2.78 \mathrm{nM}$, which is used to image the cells with the coverage of T-ZZ at (a) 0.21 and (b) 0.37 molecules $/ \mu \mathrm{m}^{2}$; (C) Control experiments were carried out using $11.12 \mathrm{nM}$ of AgMMUA, instead of AgMMUA-IgG to 
image the cells with coverage of T-ZZ at (a) 0.21 and (b) 0.37 molecules $/ \mu \mathrm{m}^{2}$; (c) incubation of $11.12 \mathrm{nM}$ of AgMMUA-IgG nanoparticles with the cells that were not attached with T-ZZ. The scale bar $=10 \mu \mathrm{m}$. 

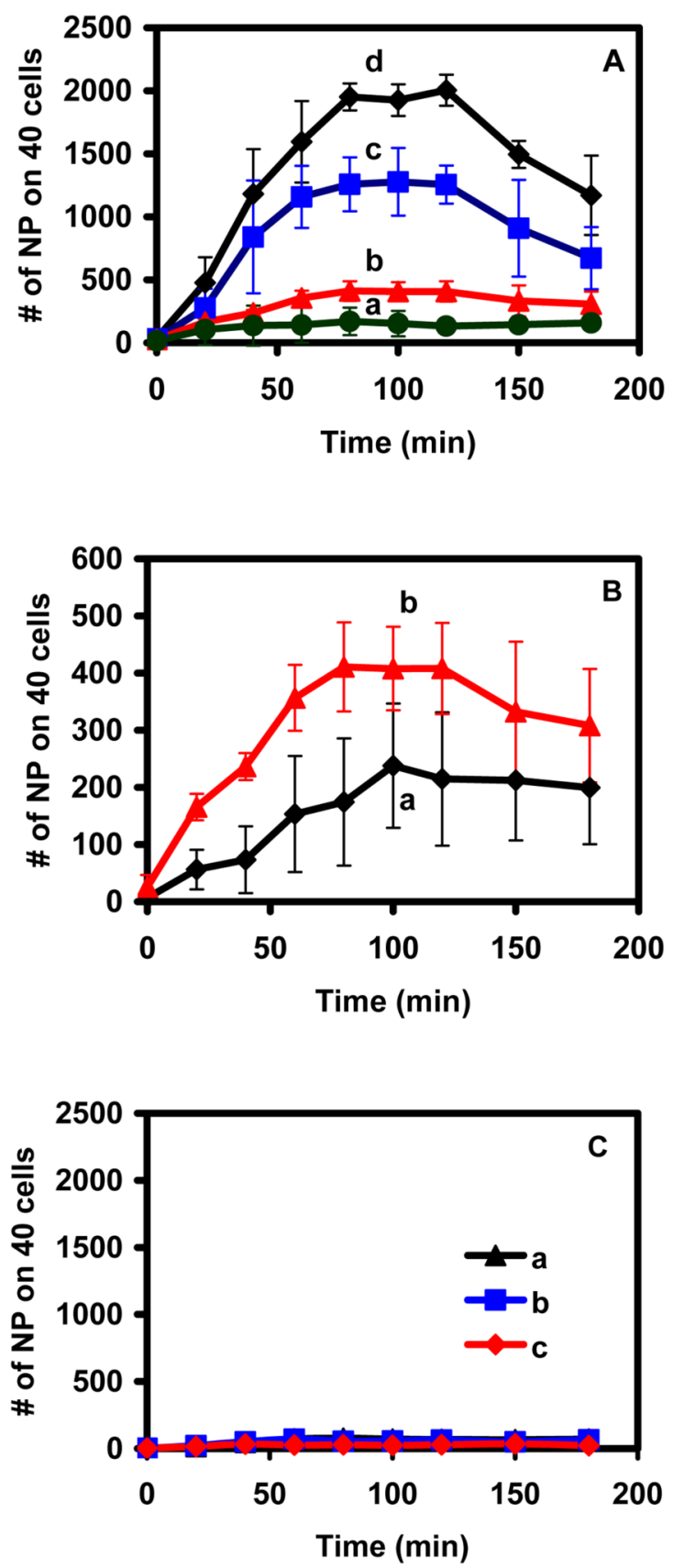

Figure 6.

Characterization of binding affinity and kinetics of AgMMUA-IgG with T-ZZ on living cells and determination of dynamic range of single nanoparticle biosensors. Plots of number of single T-ZZ molecules bound with AgMMUA-IgG nanoparticles on single living cells, acquired from images similar to those shown in Fig. 5, versus incubation time: (A) four concentrations of AgMMUA-IgG are used: (a) 1.39, (b) 2.78, (c) 5.56, and (d) $11.12 \mathrm{nM}$, as described in Fig. 5A (B) The coverage of T-ZZ on living cells: (a) 0.21 and (b) 0.37 molecules $/ \mu \mathrm{m}^{2}$, which were prepared as described in Fig. 5B; (C) Control experiments: (a-c) as described in Fig. 5C. 

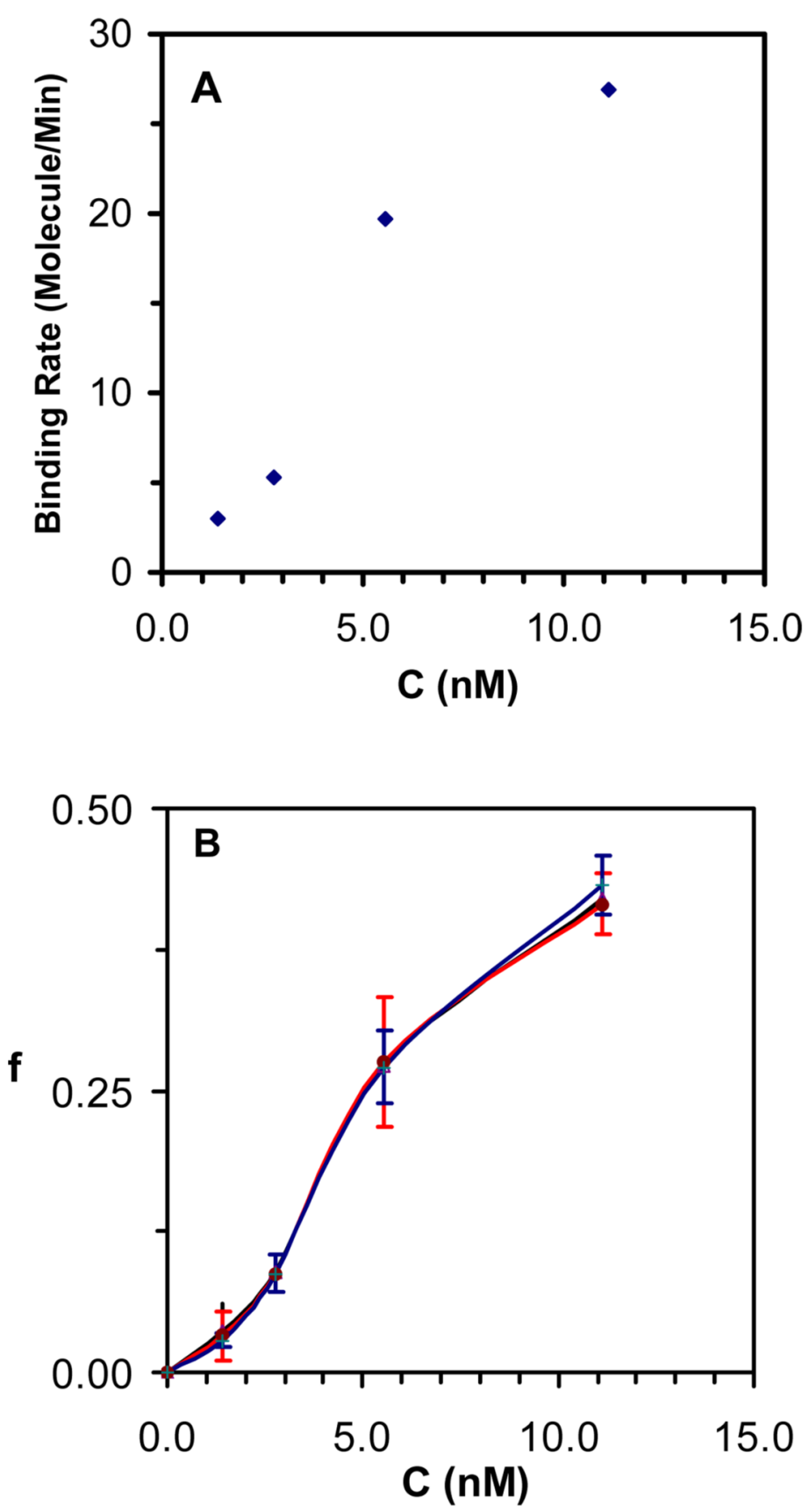

Figure 7.

Dependence of binding rates and fraction $(f)$ of T-ZZ molecules bound with AgMMUA-IgG on living cells upon the concentration of AgMMUA-IgG: (A) Plot of binding rates calculated from Fig. 6A during 0-60 min reaction time (prior to equilibrium) versus concentration of AgMMUA-IgG nanoparticles; (B) the fraction $(f)$ of bound T-ZZ molecules on living cells from Fig. 6A during 80-120 min reaction time (at equilibrium) versus concentration of AgMMUA-IgG (isotherms). The fraction $(f)$ is calculated by dividing the number of T-ZZ molecules bound with AgMMUA-IgG nanoparticles on 40 living cells with the total number of T-ZZ molecules on the living cells. 